\title{
Etiology of exanthema in children in a dengue endemic area
}

\author{
Delmina de S. Campagna, ${ }^{1}$ Marize P. Miagostovich, ${ }^{2}$ \\ Marilda M. Siqueira, ${ }^{3}$ Rivaldo V. da Cunha ${ }^{4}$
}

\begin{abstract}
Objective: To study the etiology of exanthema cases, with or without fever, in children seen in the emergency room of a hospital located in a region where dengue is endemic.

Methods: Enrollment took place between 21/09/2001 and 20/09/2002 and included $95.9 \%$ (71/74) of children presenting with exanthema at the emergency room of the Hospital Universitário de Campo Grande, MS (4.1\% refusals). After the children had had their details taken and entered on the study protocol, they were subjected to physical examination followed by collection of blood samples for blood testing with platelet counts and serology (IgM and $\mathrm{IgG}$ ); initially for dengue, rubella and toxoplasmosis and then, in negative cases, serology was also run for parvovirus, herpes virus type 6 and measles.

Results: Laboratory diagnoses were confirmed by means of IgM antibody assay in $88.7 \%$ of the cases investigated: dengue $(77.5 \%)$, herpes virus type $6(8.4 \%)$, parvovirus $(2.8 \%)$ and in eight patients diagnosis was inconclusive $(11.3 \%)$. On this occasion no positive serology (IgM) was observed for measles, rubella or toxoplasmosis. The most common clinical manifestations among the dengue patients were: fever, itching, prostration, myalgia and positive tourniquet test results. In 58.4\% (32/55) of those cases diagnosed with dengue, the tourniquet test was positive, which was a statistically significant difference when compared with the remainder of the sample.

Conclusions: When children present with exanthema, it is possible that dengue is the primary causative disease, depending on the epidemiology of the location. Constant control of epidemiological and serological surveillance of exanthematous diseases is necessary.
\end{abstract}

J Pediatr (Rio J). 2006;82(5):354-8: Exanthema, children, dengue.

\section{Introduction}

Exanthematous diseases are common in pediatric practice and are a significant cause of visits to healthcare services. ${ }^{1}$ The majority of cases have infectious etiology with systemic involvement. More than 50 causative agents of exanthema in children have been described, including viruses, chlamydiae, rickettsioses, mycoplasmas, bacteria,

1. Mestre. Pediatra plantonista, Pronto-Socorro, Hospital Universitário, Universidade Federal de Mato Grosso do Sul (UFMS), Campo Grande, MS, Brasil.

2. Doutora. Pesquisadora associada, Instituto Oswaldo Cruz (FIOCRUZ), Rio de Janeiro, RJ, Brasil.

3. Doutora. Pesquisadora titular, FIOCRUZ, Rio de Janeiro, RJ, Brasil.

4. Doutor. Professor, Departamento de Clínica Médica, UFMS, Campo Grande, MS, Brasil.

Manuscript received Mar 20 2006, accepted for publication Jun 072006 .

Suggested citation: Campagna DS, Miagostovich MP, Siqueira MM, da Cunha RV. Etiology of exanthema in children in a dengue endemic area. J Pediatr (Rio J). 2006;82:354-8. fungi and protozoans, which can cause systemic diseases associated with cutaneous manifestations. ${ }^{2}$

The epidemiological profile of exanthematous diseases in Brazil has been changing dramatically over recent years, which fact is linked to the effectiveness of the National Immunization Program. In Mato Grosso do Sul state, there were an average of approximately 367 cases of measles (clinical and laboratory diagnosis) between 1990 and 1994, while from 1995 to 1999 the average was 50 cases (laboratory confirmation), ${ }^{3}$ corresponding to vaccination coverage rates for the same periods of 79.3 and $90 \%$ respectively. 4

Initially measles vaccination was carried out at 9 months, but from 1998 onwards it was combined with rubella vaccination (at 15 months, later at 12 months), achieving a vaccination coverage rate of $94.2 \% .^{5}$ Rubella was made a notifiable disease in 1997, and that year 1,526 
cases were notified in Mato Grosso do Sul, since when the number has reduced, with 176 cases reported in $2002 .^{3}$

With relation to dengue cases in the region, an increase in incidence has been observed which also contributes to the changing epidemiological profile. The type I dengue virus was isolated for the first time in the state in 1987.6 Between 1999 and 2003 52,632 cases were reported, 19,392 of which occurred during 2002 . $^{3}$

In the context of the state's epidemiological profile as described, the primary objective of study was to identify the etiology of exanthema cases in children with or without fever, in addition to evaluating clinical data such as duration of fever, onset of symptoms, vaccination history record and associated symptoms, correlating them with the serology results.

\section{Methods}

The study enrolled 71 children aged from 28 days to 13 years who presented with exanthema at the emergency room of the Núcleo do Hospital Universitário de Campo Grande, MS, between 21/09/2001 and 20/09/2002.

With the intention of facilitating the operational aspects of the research, and in response to the major diagnostic and financial limitations faced, including the distances between major urban centers in Brazil and, consequently, between specialized laboratories, and also taking into account epidemiological issues, the following pathologies were given priority: dengue, rubella, toxoplasmosis, erythema infectiosum, exanthema subitum and measles. 3,6,7 This being so, the following diseases were not investigated: infectious mononucleosis, scarlet fever, dermatitis medicamentosa or enteroviruses.

Three children were excluded because their parents or guardians did not give permission for their participation in the Project after being informed of its nature (refusal rate of $4.1 \%$ ). The first child who initially presented with exanthema alone, progressed 2 days later to tonsillitis with purulent plaques on the tonsils, which cleared up completely after an appropriate dose of penicillin benzathine; since scarlet fever was not included in the study objectives, this case was also excluded.

The study was approved by Human Research Ethics Committee at the Universidade Federal de Mato Grosso do Sul (protocol number 124/2001). Once parents or guardians had given their consent, a datasheet was filled out containing patient identity data, duration of fever and of exanthema and previous vaccinations as confirmed by the patient's vaccination history card (at the first and/or second consultation) with their respective dates, in addition to symptoms associated with exanthema. Each child was subjected to physical examination by the researcher herself, including measurement of weight and stature.
Blood samples were taken at consultations (from 4.0 to $10.0 \mathrm{~mL}$, depending on the age group and weight of each patient) for serology and blood tests. A return appointment was made for a mean of 15 days later (with standard deviation of 1 day) for clinical reassessment and collection of a second sample so that paired samples could be studied.

All serum samples were tested for rubella, dengue and toxoplasmosis (IgM and IgG). Serology for rubella and toxoplasmosis was analyzed using a commercially-available IgM and IgG antibody micro particle enzymatic immunoassay (AXSYM SYSTEM - Abbott $^{\circledR}$ ).

Dengue IgM antibodies were assayed using IgM antibody capture enzyme immunoassay (MAC-ELISA), as described by Kuno et al. 8 Dengue IgG antibodies were assayed using a (G-ELISA) protocol that has been described in an earlier publication. ${ }^{9}$ Infections by the dengue virus (DENV) were classified as either primary or secondary according to G-ELISA titers: cases were defined as primary infections if serum IgG antibodies were $<1: 160$ during the acute phase, before the fifth day of the disease and with convalescent serum samples ( $\geq 10$ days) with titers $\leq 40,960$, while infections were defined as secondary when patients with had acute serum IgG titers of $\geq 1: 160$ and titers over 40,960 in convalescent serum. ${ }^{9}$

The technique described by Lanciotti et al. for reverse transcription followed by polymerase chain reaction (RTPCR) was used for positive acute serum samples with the intention of identifying the serotypes involved, taking the date of collection as onset of the disease. ${ }^{10}$

When patient serum tested negative for dengue, rubella and toxoplasmosis, it was processed to detect parvovirus (IgM Parvovirus B19- Biotrin ${ }^{\circledR}$ ). If that test was negative it was then tested for herpes virus type 6 , irrespective of age group (HV 6 IgM and IgG - Biotrin ${ }^{\circledR}$ ), and measles (Measles IgM kit Enzygnost Behring ${ }^{\circledR}$ ).

Patients with dengue were classed according to the World Health Organization (WHO) criteria. ${ }^{11}$ Smaller infants and children with classic dengue present undifferentiated fever that is often accompanied by exanthema; older children may present a high fever, myalgia, headaches, pain behind the eyes, arthralgia, exanthema and hemorrhagic manifestations (epistaxes, gingivorrhagia , gastrointestinal bleeding, hematuria and metrorrhagia). A definition of dengue hemorrhagic fever depends on the following: fever lasting 2-7 days, spontaneous or provoked (tourniquet test) hemorrhagic manifestations, thrombocytopenia $<100,000 / \mathrm{mm}^{3}$ and signs of thirdspace plasma loss, clinically manifest as hemoconcentration (hematocrit $\geq 38 \%$ in children), serous effusion or hypoproteinemia.

The tourniquet test was carried out using a blood pressure testing cuff (chosen to fit the size of patient) 
inflated to the point of mean blood pressure for 5 minutes. The test was considered positive when 20 or more petechiae appeared in a $2.5 \mathrm{~cm}$ area. ${ }^{2}$ Fever was defined as an axilliary temperature of $\geq 37.8^{\circ} \mathrm{C}$.

Data were analyzed statistically with Epi-Info 6.04 Centers for Disease Control and Prevention (CDC, Atlanta, GA, USA). The level of significance adopted was 0.05 , and the confidence interval was $95 \%$.

\section{Results}

The female sex predominated among these 71 patients (47 cases, $66.2 \%$ ), with a girl-boy ratio of $1.96: 1$. Age varied from 5 months to 12 years, with a mean of 5.97 years. Distribution by age group was as follows: 10 (14.1\%) children were less than 1 year old, 12 (16.9\%) were 1 to 3 years old, 12 (16.9\%) were 4 to 6 years old, $19(26.8 \%)$ were 7 to 9 years old and 18 (25.3\%) were aged 10 to 12 years.

The etiology of the exanthema was confirmed in 63 children $(88.7 \%)$, while diagnosis was inconclusive in eight patients $(11.3 \%)$. Dengue was responsible for $77.5 \%(55 / 71)$ of cases, occurring primarily among the older children; it was possible to confirm this based on the presence of IgM and by the increase in IgG titers from the first to the second samples. All six children with serology positive for herpes virus type 6 were less than 3 years old. There were two cases that were positive for parvovirus IgM.

The G-ELISA test classified 30 cases as primary infections and 25 as secondary infections. In three children the dengue 2 virus (DENV-2) was identified as the infecting serotype by means of RT-PCR (two cases of secondary infection and one primary infection).

The most frequent clinical manifestations (Table 1) among the patients with dengue were: fever, itching, prostration, myalgia and positive tourniquet tests. Positive tourniquet tests were statistically more prevalent in the dengue group $(p<0.05)$. When the prevalence ratio test is applied it can be inferred that when exanthema and a positive tourniquet test are present there is a 4.65 times greater chance of the etiologic diagnosis being dengue.

There was a statistically significant difference $(p<0.05)$ between the frequency of coughing in the group whose diagnoses were not dengue and the frequency in the group of children who were diagnosed with dengue.

All of the patients diagnosed with dengue presented the classic form of the disease, since they did not meet the WHO criteria ${ }^{12}$ for classifying them as having hemorrhagic fever. Eight of the 55 patients with dengue exhibited hemoconcentration and in 10 cases hemorrhagic phenomena were observed, with epistaxis the most common. Thrombocytopenia was confirmed in just two children, both of whom had secondary infections. It is worth pointing out that it was not the objective of this study to perform serial blood tests of platelet counts for the patients with dengue and that data is from the first consultation. Patients with reduced platelet counts were admitted until they increased once more.

Mean white blood cell counts $\left(4,614.55\right.$ cells $\left./ \mathrm{mm}^{3}\right)$ were lower for dengue cases when compared with the mean count $\left(8,418.75\right.$ cells $\left./ \mathrm{mm}^{3}\right)$ in cases where the diagnosis was not dengue $(p<0.05)$. The dengue had a median white cell count of 4,200 cells $/ \mathrm{mm}^{3}$, and their median platelets were 191,000 cells $/ \mathrm{mm}^{3}$. White cell counts varied from 2,000 to 13,000 cells $/ \mathrm{mm}^{3}$, with a standard deviation of $2,114.45$ cells $/ \mathrm{mm}^{3}$, and platelet counts varied from 25,000 to 406,000 cells $/ \mathrm{mm}^{3}$, with a standard deviation of $69,617.81$ cells $/ \mathrm{mm}^{3}$.

With relation to seasonality (Figure 1 ), it will be observed that the dengue cases primarily occurred during the months from November to February, which are the rainy months of the year in this region. The herpes virus type 6 cases were detected in October (1), November (2), April (2) and July (2), without demonstrating any seasonal pattern.

With relation to immunization history; nine children did not bring their vaccination records to either of the consultations. Rubella vaccination coverage was around $68.9 \%$, and for measles it was $85.9 \%$, although all of the children who did not bring their vaccination records were older than 3 years, thus compromising the vaccination coverage calculation. Serology (IgG) was negative for

Table 1 - Absolute and relative frequencies of clinical manifestations in 71 children exhibiting exanthema, with dengue and other diagnoses (Hospital Universitário, Universidade Federal de Mato Grosso do Sul, Brazil, September 2001 to September 2002)

\begin{tabular}{|c|c|c|c|c|}
\hline \multirow[t]{2}{*}{ Clinical manifestations } & \multicolumn{2}{|c|}{$\begin{array}{c}\text { Dengue } \\
\text { (55) }\end{array}$} & \multicolumn{2}{|c|}{$\begin{array}{c}\text { Not dengue } \\
\text { (16) }\end{array}$} \\
\hline & $\mathbf{n}$ & $\%$ & $\mathbf{n}$ & $\%$ \\
\hline Fever & 49 & 89.1 & 16 & 100 \\
\hline Itching & 45 & 81.8 & 9 & 56.3 \\
\hline Prostration & 40 & 72.7 & 8 & 50 \\
\hline Myalgia & 33 & 60 & 10 & 62.5 \\
\hline Adenomegaly & 22 & 40 & 7 & 43.8 \\
\hline Pain behind the eyes & 20 & 36.4 & 7 & 43.8 \\
\hline Abdominal pains & 17 & 30.9 & 3 & 18.8 \\
\hline Arthralgia & 15 & 27.3 & 4 & 25 \\
\hline Coryza & 12 & 21.8 & 7 & 43.8 \\
\hline Coughing & 11 & 20 & 11 & $68.8^{*}$ \\
\hline Vomiting & 8 & 14.5 & 4 & 25 \\
\hline Peeling & 2 & 3.6 & 2 & 12.5 \\
\hline Tourniquet test positive & 32 & $58.2^{\dagger}$ & 2 & 12.5 \\
\hline
\end{tabular}

* $p<0.05$.

$+p<0.05$ 
toxoplasmosis in 60 children (84.5\%). Those patients who did exhibit positive IgG were distributed across the following age groups: one $(9.09 \%)$ from 4 to 6 years, six $(54.55 \%)$ from 7 to 9 years and four (36.36\%) from 10 to 12 years.

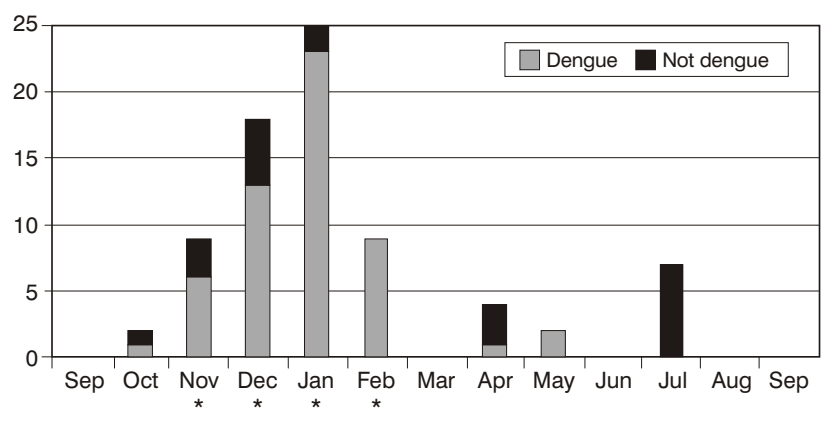

Figure 1 - Seasonality of 71 cases of children with exanthema (Hospital Universitário, Universidade Federal de Mato Grosso do Sul, September 2001 to September 2002)

${ }^{*}$ Rainy months in Mato Grosso do Sul state.

\section{Discussion}

Etiologic diagnosis of children with exanthema is not simple, epidemiology is highly important and the responsibility for paying it the appropriate level of attention in order to ensure correct conclusions rests with health professionals. In this study, even using laboratory tests, it was impossible to elucidate the etiologic agent in all cases, probably due to the large number of microorganisms that cause this symptom. $2,12-14$

Currently Brazil is going through a process of eradicating measles and controlling rubella, in common with other countries. $3,7,15,16$ Indeed, in our country the latest cases of measles to be reported have all been imported from abroad and the incidence of rubella is describing a downwards curve. In order to maintain this situation it is necessary to attain high levels of vaccination coverage, since, in this sample, it can be observed that there are still children susceptible to rubella in an age group that should already be immune.

Seroprevalence (IgG antibody assay) for rubella in this study was around $73.2 \%$, representing an increase when compared with an epidemiological survey undertaken in Ceará, ${ }^{17}$ with mean results of $56 \%$ in age groups from 2 to 9 years, and it must be pointed out that the survey was performed before the vaccination era.

Dengue has come to be a significant target of Brazilian public health concern, which is a process that began in 1986 when the dengue 1 virus (DENV-1) was introduced to the state of Rio de Janeiro and its dispersal throughout the country. ${ }^{18,19}$ In 1990 , the introduction of DENV-2 was documented, once more in Rio de Janeiro, demonstrating that the disease has become endemic and there is no cocirculation in that state and the rest of the country. ${ }^{20-23}$ In Mato Grosso do Sul, DENV-1 was first isolated in $1987 .{ }^{6}$

Infection with DENV results in a range of symptoms that can be confused with many other exanthematous diseases. ${ }^{14}$ This studied started from a symptom visible during physical examination (exanthema) before investigating the etiologic agent, finding that $77.5 \%$ of a group of pediatric patients were positive for dengue. Since the study was carried out between September 2001 and September 2002, it coincided with the period of greatest dengue incidence nationally (more than 700 thousand cases) including this state. ${ }^{7}$ In 2001, 10,927 cases of dengue were notified in Mato Grosso do South and, in 2002, there were $19,392 .^{3}$

Exanthema has already been described as common in dengue cases. 22,23 No cases of dengue hemorrhagic fever were detected as, while some children exhibited hemoconcentration, this was not accompanied by thrombocytopenia or a positive tourniquet test, and did not therefore fulfill the WHO criteria for diagnosis. ${ }^{11}$ The most common symptoms exhibited by the children with dengue were the same already listed by previously published epidemiological surveys conducted in Brazil. 22-24

In Asia, in countries such as Thailand, the Philippines and Malaysia, where epidemics have taken place since 1954 and where there is viral co-circulation of all four dengue serotypes, children primarily manifest severe and unusual forms of the disease, 25,26 in contrast with what was observed in this sample, where the majority of the children suffered from mild forms of the disease.

All of the children presenting with exanthema and testing positive for the herpes type 6 virus were less than 3 years old, confirming published data that describes exposure to this infectious agent as occurring in younger age groups. 27

One of the eight children with inconclusive diagnoses exhibited IgM positive for dengue and B19 parvovirus. Since this child did not return for the second collection, it was not possible to confirm the infection by means of IgG seroconversion. Infections by enterovirus, streptococcus or allergic reactions to medications are possible causes for the other inconclusive cases. 2,13,14

To illustrate the difficulties of diagnosis based on just data from the clinical examination of a child with exanthema, around $20 \%$ of the patients with dengue exhibited coughing or coryza, which are symptoms that characterize suspected cases of measles. Adenomegaly was present in $40 \%$ of dengue cases, while, in a study published by Oliveira in 2001,12 this was $36.1 \%$; among rubella cases there was an increased frequency $(59.1 \%)$ of adenomegaly, but this was not considered a pathognomonic sign. 
In this context the need for an up to date epidemiological and laboratory vigilance system that can make correct diagnosis and adequate control of these diseases possible, and also evaluation of the impact of measures employed, such as for example, immunization.

\section{Acknowledgements}

We are grateful to Ana Olívia Pascoto Espósito (LACEN), Marly Cássia Okunami Brisolla and Iza Keiko Hirai Akamine (LAC-NHU-UFMS), for their enthusiasm and for carrying out the laboratory tests, and to Prof. Anamaria M. Paniago, for helping with statistical analysis of the data.

\section{References}

1. Nelson JS, Stone MS. Update on selected viral exanthems. Curr Opin Pediatr. 2000;12:59-64.

2. Gable EK, Liu G, Morell DS. Pediatric exanthems. Prim Care. 2000;27:353-96.

3. Brasil, Ministério da Saúde, Secretaria de Vigilância em Saúde; 2004. http://portal.saude.gov.br/portal/svs/. Access: 09/05/ 2006.

4. Brasil, Ministério da Saúde, Fundação Nacional de Saúde, Centro Nacional de Epidemiologia. Planilhas série histórica cobertura vacinal por unidade federada, 1980-2000

5. Brasil, Ministério da Saúde, Fundação Nacional de Saúde, Centro Nacional de Epidemiologia. Dados campanha de implantação da tríplice viral/ dupla viral por unidade federada; 2000.

6. Cunha RV, Aguiar JIA, Paniago AM, Barros EMO, Hans Filho G, Barros TJ, et al. Aspectos clínicos e epidemiológicos da epidemia de dengue em Mato Grosso do Sul (MS), 1995 - resultados preliminares. In: Resumo de Temas Livres do XXXII Congresso da Sociedade Brasileira de Medicina Tropical; 1996 Mar 3-7; Goiânia, Brasil. Rev Soc Bras Med Trop. 1996;29:52-3.

7. Brasil, Fundação Nacional de Saúde. Guia de vigilância epidemiológica. 5a ed. Brasília: FUNASA; 2002.

8. Kuno G, Gómez I, Gubler DJ. Detecting artificial anti-dengue Ig $M$ immune complexes using an enzyme-linked immunosorbent assay. Am J Trop Med Hyg. 1987;36:153-9.

9. Miagostovich MP, Nogueira RM, dos Santos FB, Schatzmayr HG, Araújo ES, Vorndam V. Evaluation of an Ig G enzyme-linked immunosorbent assay for dengue diagnosis. J Clin Virol. 1999; 14:183-9.

10. Lanciotti RS, Calisher CH, Gubler DJ, Chang GJ, Vorndam AV. Rapid detection and typing of dengue viruses from clinical samples by using reverse transcriptase-polymerase chain reaction. J Clin Microbiol. 1992;30:545-51.

11. World Health Organization. Dengue haemorrhagic fever: diagnosis, treatment, prevention and control. 2nd ed. Geneva: WHO; 1997.

12. Oliveira SA, Siqueira MM, Camacho LA, Nogueira RM, Spinetti CC, Cubel Garcia RC, et al. The aetiology of maculopapular rash diseases in Niteroi, State of Rio de Janeiro, Brazil: implications for measles surveillance. Epidemiol Infect. 2001;127:509-16.
13. Oliveira MI, Curti SP, Figueiredo CA, Afonso AM, Theobaldo M, Azevedo RS, et al. Rash after measles vaccination: laboratory analysis of cases reported in Sao Paulo, Brazil. Rev Saude Publica. 2002;36:155-9.

14. De Figueiredo RM, Thatcher BD, De Lima ML, Almeida TC, Alecrim WD, Guerra MV. Exanthematous diseases and the first epidemic of dengue to occur in Manaus, Amazonas State, Brazil, during 1998-1999. Rev Soc Bras Med Trop. 2004;37:476-9.

15. Strebel PM, Cochi SL. Waving goodbye to measles. Nature. 2001;414:695-6.

16. Reef $\mathrm{SE}$, Frey $T K$, Theall $K$, Abernathy $E$, Burnett $C L$, Icenogle J, et al. The changing epidemiology of rubella in the 1990s: on the verge of elimination and new challenges for control and prevention. JAMA. 2002;287:464-72.

17. Rey LC, Barbosa LM, Osterno CL, Ramalho IL, Vilar DC, Memória AM, et al. Serologic survey of rubella in the pre-vaccine era in child-care centers, schools and maternity units of Fortaleza. J Pediatr (Rio J). 1998;74:467-72.

18. Schatzmayr HG, Nogueira RM, Travassos da Rosa AP. An outbreak of dengue virus at Rio de Janeiro - 1986. Mem Inst Oswaldo Cruz. 1986;81:245-6.

19. Figueiredo LTM. Dengue in Brazil I: history, epidemiology and research. Virus Rev Res. 1996;1:9-16.

20. Nogueira RM, Miagostovich MP, Lampe E, Schatzmayr HG. Isolation of dengue virus type 2 in Rio de Janeiro. Mem Inst Oswaldo Cruz. 1990;85:253.

21. Vasconcelos PFC, Lima JWO, Travassos da Rosa APA, Timbó MJ, Travassos da Rosa ES, Lima HR, et al. Dengue epidemic in a northeastern Brazil: random epidemiological serum survey. Rev Saude Publica. 1998;32:447-54.

22. Lima VLC, Figueiredo LTM, Correa HRF, Leite OF, Rangel O, Vido $A A$, et al. Dengue fever: a post-epidemic seroepidemiological survey in an urban setting at a northwestern county of Sao Paulo State - Brazil. Rev. Saude Publica. 1999;33:566-74.

23. Vasconcelos PF, Mota K, Straatmann A, Santos-Torres S, da Rosa AP, Tavares Neto J. Outbreak of dengue in Ipupiara and Prado, Bahia State. Seroepidemiologic survey. Rev Soc Bras Med Trop. 2000;33:61-7.

24. da Cunha RV, Dias M, Nogueira RM, Chagas N, Miagostovich MP, Schatzmayr HG. Secondary dengue infection in schoolchildren in a dengue endemic area in the state of Rio de Janeiro, Brazil. Rev Inst Med Trop Sao Paulo. 1995;37:517-21.

25. Thisyakorn U, Thisyakorn C. Dengue infection with unusual manifestations. J Med Assoc Thai. 1994;77:410-3.

26. Endy TP, Nisalak A, Chunsuttiwat S, Libraty DH, Green S, Rothman AL, et al. Spatial and temporal circulation of dengue virus serotypes: a prospective study of primary school children in Kamphaeng Phet, Thailand. Am J Epidemiol. 2002;156:52-9.

27. Chua KB, Khairullah NS, Hooi PS. Seroepidemiology of human herpesvirus 6 in a population seen in the University Hospital, Kuala Lumpur, Malaysia. Southeast Asian J Trop Med Public Health. 1996;27:91-5.

\section{Correspondence:}

Delmina de Souza Campagna

Rua Madressilva, 70, Carandá Bosque II

CEP 79032-380 - Campo Grande, MS - Brazil

Tel.: +55 (67) 3025.2125, +55 (67) 9983.8087

Fax: +55 (67) 3327.2973

E-mail:dcampagna@uol.com.br 